\title{
Defining Diaspora in post-Yugoslav States
}

\author{
DANIJELA VUKOVIĆ-ĆALASAN \\ Faculty of Political Sciences, University of Montenegro, Podgorica \\ SINIŠA TATALOVIĆ \\ Faculty of Political Sciences, University of Zagreb
}

\begin{abstract}
Summary
Contemporary societies exist in the conditions of globalisation, which profoundly transforms them in different dimensions. Technological progress enabled the significant changes in the identity dimension. This has, inter alia, resulted in new opportunities for preserving identification with the country of origin, increased interest in the diaspora concept in the politological and sociological thought and caused new approaches and activities by the states in improving relations with their diasporic communities. The former republics of the SFRY, which have been making progress in building legal and institutional capacities for cooperation with diasporas, are no exception. Generally, all of these countries have very numerous and diverse diasporas, which have usually been emerging in a long period of time. This paper analyzes the policies of the states, created by the break-up of the SFRY, towards their diasporas. The policies of these states are specific and they differ from one another, both in defining diaspora and in legal and institutional solutions that should improve diaspora's link with the country of origin. However, the Republic of Slovenia, the Republic of Croatia, Bosnia and Herzegovina, the Republic of Serbia, Montenegro and the Republic of North Macedonia, have some common elements as well.
\end{abstract}

Keywords: Diaspora, Globalisation, Post-Yugoslav Countries, Identity, Ethnocultural Communities

\section{Introduction}

Diaspora is one of the terms that became topical and omnipresent in political, legal and sociological thought at the end of the 20th century. Globalisation processes in all socio-economic, political, as well as identity dimensions, have been deeply 
transforming the nation-state contexts in a different and often contradictory way. The abolition of time and space through the possibility of constant communication and overcoming the spatial distances in a relatively easy and inexpensive way, makes the technological dimension of globalisation the main creator of the new context (Bek, 2011). Due to this dimension, which is also a prerequisite for modern, accelerated globalisation since the end of the 20th century (Šolte, 2009), the ethno-cultural communities worldwide have been given the opportunity to maintain the strong ties with their country of origin. The character of immigration has been changing and there is a sense of divided loyalty and identification in regards to country of reception and country of origin. Along with this change, since the second half of the 20th century, the attitude of liberal-democratic states towards the ethno-cultural minorities has changed significantly. Assimilation is no longer acceptable, while in the relation of democracies towards the ethno-cultural pluralism, the multiculturalism model has been rising within their borders. This entails various socio-economic, political and legal measures and mechanisms that enable the ethno-cultural and the ethno-national minorities to preserve their identity, which is being recognised in the public sphere and through different, constitutionally and legally guaranteed minority rights (Anteby-Yemini, Berthomiere, 2005). These reasons make the diaspora concept topical in contemporary circumstances. States are increasingly paying attention to their expatriates, developing ways to valorise their diaspora in economy, politics, science and culture. In 2013, according to Gamlen, more than one hundred countries had at least one institution dealing with diaspora issues and its relation with the country of origin (in Garding, 2018: 353). ${ }^{1}$ This also applies to the countries created by the break-up of the SFRY, which have numerous diasporas in European and overseas countries, mostly in North and South America, and Australia. These diasporas had gradually emerged since the end of the 19th century, due to the economic and political reasons. The largest diasporas emerged after the Second World War, with the so-called "hostile" or political emigration, and emigration of the so-called "temporary workers abroad". A special and numerically largest diaspora consists of refugees due to the wars and political crises in the dissolution process of the SFRY. The main objective of this paper is to analyze policies of the former SFRY countries towards their diasporas. It starts with an assumption that the policies of these states differ from one another, but they also have some common elements, primarily due to their experiences regarding diasporas in the former common state.

1 More details about the trend of increasing institutional capacity of states for cooperation with diasporic communities in the period 1980-2014, in: Gamlen (2014: 182). 


\section{The Diaspora Concept - Change in Meaning}

Since when does the term "diaspora" date and has there been any change in its meaning in terms of value, in different periods of its use? Authors usually emphasise that this term originally meant forced immigration or displacement of a particular community, motivated by various, most often catastrophic and traumatic events (Cohen, 1996; Ellis, 2006). In that sense, diaspora members were mostly victims of certain conflicts, processes or events and, therefore, they were forced to immigrate. Very often, this tradition of understanding diaspora entailed an intention as well as deep desire of a community to return to its country of origin. This is the so-called "negative (victim) tradition of diaspora", or the one that is primarily related to the Jewish tradition of diaspora (Cohen, 1996: 4). Such negatively valued meaning of the term remained until the end of the 20th century. ${ }^{2}$ However, the meaning of diaspora concept cannot be reduced only to forced immigration and colonisation. It is much more complex and it strives to include major changes in sphere of migrations, socio-economic and political circumstances, mostly during the 20th century. In that sense, Cohen's definition of diaspora is the most cited one, as it strives to encompass many other - more specific or narrower - meanings of the term and thus provide a broader definition. He distinguishes the following characteristics, common for different diaspora concepts: " 1 . Community displacement from a country of origin in two or more regions outside of its borders, which is usually traumatic; 2. Or, community expansion from its country of origin in search of work, in order to engage in trade or for pursuing colonial ambitions; 3. Existence of a collective memory and myth of a homeland, related to its territory, history or achievements; 4. Idealisation of an imagined ancestral land and a sense of collective commitment to its preservation, restoration, protection and prosperity, even its re-creation; 5. Existence of a movement for return to a homeland, as a country of origin, that manages to get collective support; 6 . Existence of the strong ethnic self-awareness over a long period of time, based on a sense of diversity, common history and belief in existence of collective fate; 7. A problematic relation between a receiving society and a community, in terms of lack of acceptance or sense of a potential new disaster that could hit the community; 8. A sense of empathy and solidarity towards their ethnic community members that are located in other countries; 9 . A possibility of having a special, creative and enriched life in a receiving country, where tolerance towards pluralism exists" (in Anteby-Yemini, Berthomiere, 2005: 264).

2 Cohen points out that the term "diaspora" in Greek translation of the Bible implies the widespread construction, and that it referred to the colonisation of Asia Minor and the Mediterranean in 800-600 BC. Although the colonisation was motivated by poverty, conflicts and overpopulation, in this case the term had a slightly more positive connotation (Cohen, 1996: 1). 
It is clear that Cohen's definition of diaspora is quite broad and it can involve the communities whose emigration was motivated by a traumatic event or colonisation, as well as those diasporas that emerged primarily as a result of the need to achieve a better quality of life, in the economic and political sense. However, this definition has been much criticised as well, especially in the part concerning the understanding of diasporic communities as more or less homogeneous entities, as well as the part concerning the desire to return to a country of origin. In case of diasporas which emerged as a result of the new migratory waves during the 20th century, certain characteristics are less significant or almost non-existent, such as existence of a strong movement for return to a homeland or existence of a problematic relationship with a receiving country. Globalisation has provided the ability to maintain a strong ethnic identity and sense of identification and loyalty towards a country of origin, along with an achieved integration in a receiving country and desire to continue living in it. Other elements indicate that it is an ideal type of diaspora, whose characteristics can be found, more or less, in a specific nation-state context of a receiving country. ${ }^{3}$

This kind of definition of the term "diaspora" avoids the misleadings of its narrow definition, that binds it solely to alienation, isolation, nostalgia and desire to return to a homeland (Majnhof, Triandafilidu, 2008: 274). In this paper, we accept this, broader, definition of diaspora and we consider it more appropriate in contemporary circumstances, created by the globalisation processes ${ }^{4}$ However, it is advisable to draw attention to a new approach, which is being developed by Ulrike Hanna Meinhof and Ana Triandafilidu. This approach justifiably indicates that diasporic communities members, especially immigrants, have been exposed to the various cultural and identity practices (not only those concerning the national culture of a receiving country and cultural practices of a country of origin) which exist

3 There have been many attempts to similarly define the term "diaspora". Thus, William Safran provides his ideal-typical definition of diaspora that has ten elements. The characteristics mostly coincide with those distinguished by Cohen, while emphasising that the diasporic communities strive to continue living in the receiving country with the minority status, while preserving their identity and becoming the center of a new cultural identity constitution, with elements of the ethno-cultural community they belong to. Also, he emphasises the importance of various diasporic organisations, through which the communities establish and maintain the relations with their home country. Diasporic communities are those whose members or their descendants tend to return to their country of origin and believe that they can never be fully accepted into the receiving society (Safran, 1991: 83-84).

${ }^{4}$ It should be recalled that the era of globalisation is often defined as the era of migrations. It is estimated that the trend of migratory movements will continue. According to UN reports from 2019, the number of migrants is growing faster than the world population and currently their number is approx. 272 million. More at: https://news.un.org/en/story/2019/09/1046562 (accessed 20 February 2020). 
and act in parallel, at different levels. Any consideration of diasporic communities in contemporary, globalising circumstances, must take into account the aforementioned fact. They distinguish diaspora, (neo-)communitarianism and cosmopolitanism as the three most significant discourses in studying migrations and a common term has been used for all the three - transnationalism. Broader definition of diaspora should include the (neo-)communitarian approach, that also emphasises the relation between a community and a receiving country, and often, the absence of desire to return, while the community maintains strong ties with a country of origin. A comprehensive definition of contemporary diasporic communities should not neglect the exposure of community members to the so-called cosmopolitan practices. They are primarily related to the influence of the various ethno-cultural communities, which an individual comes in contact with, as well as the influence that consumerism, as the main unifying force of the contemporary globalisation processes, has on diaspora members. As the authors rightly point out, diasporic, (neo-)communitarian and cosmopolitan approaches are often related and intertwined in practice, offering different levels of identification for migrants, in different circumstances (Majnhof, Triandafilidu, 2008: 274). That way, the misleadings of the mentioned narrow definition of diaspora that sees a community solely in the light of potential return to a homeland, are being avoided, as well as the misleadings of the broadest cosmopolitan approach, which mostly fails to acknowledge the importance that a country of origin has for an ethnic community, ignoring the relations between them (ibid.: 275). ${ }^{5}$ This applies to communities that have been present in a territory of a state (national, historical minorities) for a long period of time, as well as to diasporas that emerged as a result of migratory movements in different periods of time. In addition to diaspora definition and different approaches to this concept, an important issue related to this is the issue of different types of diaspora. There have been numerous attempts to typologise and classify diasporas. A typology of diasporas helps in understanding the diasporic communities and brings more clarity in a myriad of specificities of different contexts. It is important to notice here that the understanding of diasporic communities is certainly contextual and it depends on the specificities of the country of origin in cultural, identity, political and every other sense, as well as the specificities of the receiving country, identity of the diasporic community itself etc.

Cohen, for instance, in his famous typology of diaspora, distinguishes the following types of diaspora: Victim/Refugee, Imperial/Colonial, Labour/Service, Trade/Bussiness/Professional, Cultural/Hybrid/Postmodern (Cohen, 1997: 178). In

${ }^{5}$ It should be considered that the members of different diasporic communities are exposed in different degrees to cosmopolitan practices. This depends, inter alia, on their economic position, access to technology, especially in the field of communication, etc. 
terms of relation between a country of origin and its diasporic communities, it is possible to distinguish a few approaches, some of which dominate more than others in each concrete case, or they intertwine. Maria Koinova and Gerasimos Tsourapas recognise the following approaches: Utilitarian, Identity-based, Governance perspective and Socio-spatial perspective (Koinova, Tsourapas, 2018: 313). Utilitarian approach is characteristic for countries of origin that are primarily interested in diasporic communities as a source of material, economic or political gain. The method of economic valorisation of diaspora may be different, from sending certain amounts of money annually through remittances, which can significantly reduce unemployment in a country of origin, to the effort for diasporas to engage themselves in their countries of origin, by investing, tourist activities and activities in the field of scientific cooperation and expertise. Also, this approach implies the use of diaspora in pursuing political goals of the country of origin in the receiving country (ibid.). Identity-based approach considers diaspora primarily through a prism of symbolic power and activities that should strengthen the ties with its country of origin, in terms of strengthening and preserving the national identity of the country of origin among the diasporic communities members. Thus, the countries of origin primarily focus on organising the "diaspora days", supporting the diasporic media, religious communities in receiving countries as centres of diasporic gathering, as well as financing the lessons of language and history of the country of origin, etc. The third approach is the so-called governance perspective. This approach has become more significant with the beginning of the migrant crisis in 2015, and its focus is on managing the immigrant communities through the cooperation between the country of origin and, most often, more than one receiving country. The emphasis here is on the institutional, administrative activity of states and others in the best possible response to the new migratory trends.

\section{The Former SFRY Republics and the Diaspora Concept}

Until the creation of the Kingdom of the Serbs, Croats and Slovenes, later the Kingdom of Yugoslavia, the territories it covered were exposed to constant migrations, due to the previous wars or borders changes. In the 20th century, there had been internal migrations within the Yugoslav territory, and external migrations to the European and other territory. There had also been a few migratory waves between the two World Wars, after the Second World War, and during and after the postYugoslav wars. The reasons for migrations were mostly of economic and political nature. Thus, from the end of the 19th and into the 20th century, all the Yugoslav nations got their, larger or smaller, diasporas. The formation and development of these diasporas in different periods of time and regions of the world were related to the situation in their country/countries of origin. The SFRY had a designed policy 
towards its diaspora, dividing it into diaspora that was considered as "hostile", towards which repressive measures were taken, and the one it regarded as part of the Yugoslav peoples abroad, closely related to those peoples in the Homeland. A special category were "temporary workers abroad", who were not considered a classical diaspora.

Thus, it was considered that, in Yugoslavia, "going abroad to work after the Second World War began around 1954, and mostly by going to work in France and Germany. This spontaneous, and in the beginning quite unallowed abandonment of the country in search of work and better earnings, particularly increased in 1962. In 1964, Yugoslav political and state institutions accepted employment abroad as a necessity in the socio-economic context of the time. Since then, the Yugoslav Employment Service had been increasingly cooperating with foreign employers and services on organised employment of Yugoslav workers abroad" (Baučić, 1971/1972: 26). Post-Yugoslav diasporas, particularly those that the SFRY considered "hostile", readily got involved in its dissolution and the process of constituting the new nation-states. Thus, significant parts of diasporas have greatly influenced the policies of the post-Yugoslav countries, bringing some values from the past times into them, that were supposed to be overcome. As opposed to them, new, especially intellectual, diasporas, which emerged in the 1990s and have intensively been dealing with different processes in the post-Yugoslav territory, have had an increasingly significant influence.

How do these six states define the diaspora concept and are there any significant changes in its definition? Comparison of diaspora definitions in current regulations of the Republic of Slovenia, the Republic of Croatia, Bosnia and Herzegovina, the Republic of Serbia, Montenegro and the Republic of North Macedonia, indicates that a distinction can be made between the two basic approaches in diaspora definition. Those countries that accept the first approach, make a difference between the population (that considers them their home countries) living in the region and neighbouring countries and the population living in other countries and regions of the world. The Republic of Slovenia, the Republic of Croatia and the Republic of Serbia adopted this approach and they make the terminological difference between these two categories, using the term diaspora for their communities located outside of the region. Thus, the Republic of Slovenia, in its first legal document in 1996, directly referring to Slovenians living outside of Slovenia, Resolution on the position of autochthonous Slovene minorities in neighbouring countries and the related tasks of state and other institutions in the Republic of Slovenia, deals exclusively with the position of Slovenians in the neighbouring countries, who have an autochthonous minority status there. This document states that the Republic of Slovenia provides financial assistance to the autochthonous Slovene minority organisations 
operating in the Republic of Austria, the Italian Republic, Hungary and the Republic of Croatia. Various economic policy measures, financed by funds secured from the Slovenian state budget, tend to strengthen the economic ties between the Republic of Slovenia and the autochthonous Slovene minorities in the neighbouring countries, which, as stated in the Resolution, is also one of Slovenian permanent and strategic interests (Državni zbor Republike Slovenije [National Assembly of the Republic of Slovenia], 1996). According to the Act Regulating Relations between the Republic of Slovenia and Slovenes Abroad, adopted in 2006, Slovenians outside the Republic of Slovenia are equal members of the Slovenian nation and they are protected by the state, and Slovenians abroad include members of the autochthonous Slovene minorities in the neighbouring countries (the Republic of Austria, the Italian Republic, Hungary and the Republic of Croatia) and Slovenian migrants worldwide. This Act applies to Slovenes abroad with Slovenian citizenship, those who are recognized as Slovenes but do not have citizenship and to Slovenes without recognized status. Concern for them, presented in this Act, is an integral and essential part of the Republic of Slovenia's foreign policy and it is stated that the relations with Slovenians outside Slovenia are built through institutional integration, the strengthening of the Slovenian national communities in the neighbouring countries and around the world, and through financial assistance (Vlada Republike Slovenije [Government of the Republic of Slovenia], 2006c).

The 2009 Law on Diaspora and Serbs in the Region, made a clear distinction between "diaspora" and "Serbs in the region". Diaspora includes the citizens of the Republic of Serbia that live abroad, but expatriates as well, members of the Serb nation from the territory of Serbia and from the region, and their descendants. Therefore, the term diaspora is related to political and economic emigration and it refers to all the citizens of the Republic of Serbia abroad and their descendants, regardless of their ethnic, national or religious affiliation (Obraćanje Ministra za dijasporu, mr Srđana Srećkovića [Address of Minister for Diaspora, MA Srđan Srećković...], 2009). The terminological construction "Serbs in the region" refers to Serbs living in the Republic of Croatia, the Republic of Slovenia, Bosnia and Herzegovina, Montenegro, the Republic of North Macedonia, the Republic of Albania, Romania and the Republic of Hungary. In these contexts, Serbs are considered to be the autochthonous population that has been present for a long historical period of time and they do not belong to diaspora. In relation to the aforementioned categories of population, Serbia is legally positioned as their homeland (Zakon o dijaspori i Srbima u regionu [Law on Diaspora and Serbs in the Region], 2009: 1).

Numerous Croat minorities in the neighbouring countries, as well as large diaspora, have influenced Croatia to formulate and implement specific policies concerning Croats outside Croatia. Thus, the state of Croatia recognises three catego- 
ries of Croats living outside the borders of the Republic of Croatia, and in relation to which it positions itself as the homeland and implements various policies: Croat diaspora, Croat minorities in other countries, and Croats as constituent people in Bosnia and Herzegovina. Each one of these policies has its own specificities. Since the 15 th century, due to various historical, political and economic reasons, Croats have begun to emigrate from Croatian territories, so nowadays, their descendants live as the autochthonous minority communities in twelve European countries. ${ }^{6}$ Their position and status have been regulated differently in each of these countries, so the extent and level of their rights are also different from country to country (Hrvatiizvanrh.gov.hr, 2020).

Unlike the previous three countries, Montenegro, Bosnia and Herzegovina and the Republic of North Macedonia have a slightly different approach in defining diaspora. The Montenegrin legislation uses exclusively the term "diaspora", as well as "emigrants". Diaspora definition was given in the 2018 Law on Cooperation of Montenegro with Diaspora. According to Article 2 of this Law, "Diaspora - emigrants are Montenegrin citizens and other persons originating from Montenegro, who live abroad and perceive Montenegro as their homeland or country of origin and inherit it as democratic, independent, sovereign and civic" (Zakon o saradnji Crne Gore sa dijasporom [Law on Cooperation of Montenegro with Diaspora], 2018). Paragraph 2 of this Article states that those Montenegrin citizens that are residing abroad with no intention to stay there permanently, are not diaspora - emigrants. Thereby, Montenegro considers the aforementioned category of population to be its diaspora - emigrants, regardless of whether they live in the region or somewhere else, regardless of which national or ethnic community in Montenegro they belong to and irrespective of the generation of expatriates they belong to.

When it comes to defining diaspora in Bosnia and Herzegovina, internal division is noticeable. The constituent entities, primarily the Republic of Srpska, and the central government authorities do not agree on diaspora definition and the way this issue should be dealt with at the state level. This results in different approaches to this issue and parallel activities at different levels and it produces an inconsistent and uncoordinated policy towards diaspora. The attempt to introduce the concept of unified Bosnian-Herzegovinan diaspora and treat it as such, the Republic of Srpska authorities perceive as an imposition of the artificial and the non-existent, as well as continuation of attempts to centralize or unitarize Bosnia-Herzegovina and they do not agree with that. Instead of the unified Bosnian-Herzegovinan diaspora, they in-

6 The Republic of Austria, the Republic of Bulgaria, Montenegro, the Czech Republic, the Italian Republic, the Republic of Kosovo, Hungary, the Republic of North Macedonia, Romania, Slovak Republic, the Republic of Slovenia and the Republic of Serbia (Hrvatiizvanrh.gov.hr, 2020). 
sist on the existence of separate Serb, Bosniak and Croat diasporas and they believe that the only justifiable approach would be the one that would make such distinction in the relation between the state and diaspora, that is, diasporas ("SARAJEVO ŽELI...", 2018). After conducting qualitative and quantitative research in ten countries where the diaspora of Bosnia and Herzegovina is significantly present, a group of social scientists have offered, inter alia, an inclusive definition of diaspora, which should overcome these disagreements. ${ }^{7}$ According to them, diaspora of Bosnia and Herzegovina includes "persons that migrated due to war, but also their descendants and previous generations of migrants from Bosnia and Herzegovina, who maintain their identities from the mentioned country" (Halilović et al., 2018: 222). Bosnia and Herzegovina has not adopted a law governing this area yet, mainly due to the previously mentioned socio-political circumstances.

According to the official definition of Macedonian Ministry of Foreign Affairs, the concept and the term diaspora defines, that is, includes Macedonian national minorities in other countries and migrants (persons who used to have Macedonian citizenship), as well as Macedonian citizens living and working abroad, and ethnic Macedones that have never had Macedonian citizenship (Ragazzi, Balalovska, 2011).

All the former republics of the SFRY have a very large diaspora. They also have in common the lack of accurate databases and track of number of their diasporic communities members. ${ }^{8}$ It is only recently that these countries strive to ensure

7 The survey was conducted in the second half of 2017, in the ten receiving countries with the largest number of persons from Bosnia and Herzegovina (including those with origins from Bosnia and Herzegovina): Commonwealth of Australia, the Republic of Austria, the Kingdom of Denmark, the Federal Republic of Germany, the Italian Republic, the Netherlands, the Republic of Slovenia, the Kingdom of Sweden, the Swiss Confederation, and the United States.

${ }^{8}$ When it comes to the number of diasporic communities, these countries usually include descendants of second or third generation of expatriates. Unlike other former republics of the SFRY, in Montenegro, the Republic of Slovenia and the Republic of Croatia, the descendants of emigrants are considered diasporas, regardless of the generation they belong to. Although there are no precise data, it is usually emphasised that another Montenegro lives outside the borders of Montenegro. By comparing the available sources, we can determine that the size of the Slovenian diaspora ranges between 300.000 and half a million (Prešeren, 2001; Žigon, 1993). The official website of the Slovenian Government lists about half a million Slovenes and Slovene descendants living outside of the Republic of Slovenia, representing approx. one fifth of the Slovenian national body (Vlada Republike Slovenije [Government of the Republic of Slovenia], 2019). As in other former republics of the SFRY, the absence of census and accurate data resulted in the absence of an exact number of diaspora members of the Republic of Serbia. The 2011 Strategy for maintaining and strengthening the relations between the home country and diaspora or between the home country and Serbs in the region, mentions the figure of approx. 4 million diaspora members (including the second and third generations), living outside the borders of the Republic of Serbia, out of which approx. 1.5 million live in Europe and approx. 1 million live in 
keeping more accurate records and database of emigrants, and the mentioned usually becomes an obligation of the institution under whose jurisdiction the diaspora issue is.

\section{Legal and Institutional Framework for Regulating the Diaspora Issue in the Former SFRY States}

In order to regulate a relation between diaspora and a country of origin, it is of primary importance that a well-regulated legal framework exists, which regulates this area in a complete and functional manner. It is clear that the states started the legal regulation of this area relatively late, mostly after 2000. Some of them had previously dealt mainly with their people members living in the neighbouring countries and the region, and their position. All these countries, with the exception of Bosnia and Herzegovina, regulate this area by a separate law or series of by-laws. In April 2017, The Council of Ministers of Bosnia and Herzegovina adopted the Policy on cooperation with Diaspora, as a framework document regulating this area, without consent of the Republic of Srpska. At the moment, there is no consent when it comes to adoption of the announced Strategy of Bosnia and Herzegovina on co-

overseas countries (Ministarstvo vera i dijaspore [Ministry of Religion and the Diaspora], 2011: 2, 6). As for Bosnia and Herzegovina, if the descendants of the second and third generations are taken into account, although this piece of information is not precise, there are more then 2 million persons, which is approx. $50 \%$ of the entire population of Bosnia and Herzegovina (Halilović, Hasić, Karabegović, Karamehić-Muratović, Oruč, Mapping the Bosnian-Herzegovinian Diaspora; 2018: 7). In the case of the Republic of North Macedonia, data on diaspora size vary. According to data released by the World Bank Group in 2010, Macedonian diaspora is estimated at 447.000 emigrants, i.e. one fifth of the entire population of the Republic of North Macedonia. In the 2008-2010 period, according to EUROSTAT, there were 230.000 Macedonian diaspora members living in the EU countries (Bechev, 2019). However, the exact figure has not been determined yet, so it is speculated that there are between 350.000 and 2 million Macedonian emigrants worldwide. It is estimated that the largest economically-caused Macedonian communities in diaspora are located in Canada, the United States and Commonwealth of Australia, at approximately 580.000 emigrants worldwide (Topolinjska, 1998). Finally, in order to determine the number of Croats living outside the Republic of Croatia, the following Croats must be taken into consideration - Croatian expatriates and their descendants living in overseas and European countries, the Croatian minority members living in European countries and Croats living in Bosnia and Herzegovina, as one of the three constituent peoples (Hrvatski sabor [Croatian Parliament], 2012). According to data available on the Central State Office website pages, designed for Croats living outside the Republic of Croatia, there are approximately 3 million Croatian expatriates and their descendants and Croatian minority members living outside the Republic of Croatia, while approx. half a million live in Bosnia and Herzegovina (Hrvatiizvanrh.gov.hr, 2020). In accordance with the latest 2011 census, a little more than 3.8 million Croats lived in Croatia at the time, thus, according to the figures presented above, we can conclude that there are about as many living outside the Republic of Croatia (Dzs.hr, 2011). 
operation with her diaspora either, or adoption of the Law on Diaspora of Bosnia and Herzegovina. This indicates the continuation of the trend of different policies towards diasporic communities of Bosnia and Herzegovina, at different authority levels. This division reflects on the organisations as well, that is, the associations of diasporic communities, which individually and mostly bring together members of one of the peoples of Bosnia and Herzegovina.

The Republic of Slovenia adopted the essential documents concerning relations with diaspora ten years after adopting the Resolution on Slovenes in the neighbouring countries. In addition to the aforementioned Act Regulating Relations between the Republic of Slovenia and Slovenes Abroad from 2006, in the same year, four more documents were adopted as the result of it: the Resolution on organising the work area of the Government Office for Slovenians abroad, which regulates the work area of the Office in more detail; the Decision on the organisation and competence of the Government Office of the Republic of Slovenia for Slovenes in the neighbouring countries and the Decision on the organisation and competence of the Government Office of the Republic of Slovenia for Slovenes abroad, that established the Council for Slovenes in the Neighbouring Countries and the Council for Slovenes Abroad; and the Decree on the granting of financial support for the maintenance and development of the Slovene identity outside of the Republic of Slovenia, which defines the ways of providing financial support to structures and activities carried out by Slovenes outside the state borders, but also to individuals, institutions, associations and organisations operating in the Republic of Slovenia (Vlada Republike Slovenije, 2006a, 2006b, 2006c, 2006d).

In the case of the Republic of Serbia, in the normative sense, this area is regulated primarily by the Constitution of the Republic of Serbia, the Law on Diaspora and Serbs in the Region from 2009, the Law on Ministries from 2014 and Strategy for maintaining and strengthening the relations between the homeland and diaspora or between the homeland and Serbs in the region from 2011, as well as other laws and strategies, which, in certain parts, regulate issues of importance to the diaspora. Article 13 of the Constitution of the Republic of Serbia prescribes the obligation of the Republic of Serbia to protect the rights and interests of Serbian citizens abroad, but also to improve relations between the Republic of Serbia as the homeland and Serbs living outside its borders (Ustav Republike Srbije [Constitution of the Republic of Serbia, 2006). The events in the identity dimension within Montenegro throughout its history, have reflected on its diaspora's nature, which is mostly divided, disorganised and complex. This was also noted in Strategy of cooperation with Diaspora for the period 2011-2014, adopted by the Ministry of Foreign Affairs of Montenegro. Namely, the aforementioned Strategy draws attention to the fact that, after the break-up of the SFRY and to this day, the diasporic communities of Mon- 
tenegrin expatriates have mainly been gathering around religious, native or ethnic organisations, thus the diaspora organisations have not shown major capacity for gathering Montenegrin diaspora that would overcome these divisions (Vlada Crne Gore. Strategija saradnje sa dijasporom za period 2011-2014. [Government of Montenegro. Strategy of cooperation with Diaspora for the period 2011-2014], 2010: 5). The first Law on Cooperation with Emigrants was adopted in 2015, while in 2018, the Parliament of Montenegro adopted the Law on Cooperation of Montenegro with Diaspora - Emigrants, which regulated diaspora in a more complete way. Apart from these documents, Strategy for cooperation with emigrants for the period 20152018 should also be mentioned as another significant legal and strategic document that regulates the cooperation between diaspora and Montenegro as the homeland. This Strategy, as its most general goal, proclaims the need to preserve a sense of belonging to Montenegro as the home country among the members of Montenegrin diaspora (Vlada Crne Gore. Strategija..., 2015). The Constitution of Montenegro did not prescribe an obligation to maintain relation with emigrants, unlike the aforementioned Constitution of the Republic of Serbia, but also the Constitution of the Republic of Croatia, which stipulates that the country shall "safeguard the rights and interests of its citizens living or residing abroad, and shall promote their ties to their homeland. The Republic of Croatia shall guarantee particular care and protection to those parts of the Croatian nation in other countries" (Hrvatski sabor [Croatian Parliament], 2014: 6). The first legal document exclusively related to Croats outside Croatia is the Law on Relations between the Republic of Croatia and Croats outside the Republic of Croatia, adopted in 2011. The Law applies to the members of the constituent Croat people in Bosnia and Herzegovina, Croat minorities in European countries and Croatian expatriates in overseas and European countries and their descendants, who are: Croatian citizens and have the "status of Croats without Croatian citizenship" or who are Croats outside the Republic of Croatia, without Croatian citizenship and status.

The formal-legal relationship between Macedonian state and diaspora members began relatively late, in 2006, by adopting the Law on Foreigners, whose implementation started in 2008. The Constitution of the Republic of North Macedonia, i.e. its amendment XXXVI, guarantees the protection of the rights and interests of Macedonian diaspora worldwide.

In the institutional sense, the states have opted for, to a certain extent, similar solutions in achieving the goals set by the legal acts. Most of the former SFRY states, in the institutional sense, strive to ensure the multisectoral approach, which would integrate the activities of all institutions, whose competence is indirectly or directly related to diaspora. This is especially the case in the Republic of Slovenia, the Republic of Croatia, Montenegro and the Republic of Serbia. Institutionally, the 
states have mostly accepted the solution that entails establishing a main institution for dealing with this issue, at the office or administration level, therefore, lower than the ministerial one. The Republic of Serbia is an exception, as it has a ministry responsible for diaspora, as well as the Republic of North Macedonia, where the Minister without portfolio is responsible for diaspora. In order to get the main representatives of cooperation between the Republic of Slovenia and Slovenes outside its borders, two representative bodies were established: Government Office for Slovenes Abroad, as the central state administration body dealing with the cooperation issue, and the Commission for Relations with Slovenes in Neighbouring and Other Countries, which is the working body of the National Assembly (Državni zbor Republike Slovenije [National Assembly of the Republic of Slovenia], 2006). Central State Office for Croats Abroad is the central state administration body responsible for relations between the Republic of Croatia and Croats outside its borders, whose area of competence, inter alia, includes coordinating and supervising the activities among competent ministries and other bodies and representatives of the cooperation between the state and Croats abroad, developing a communication strategy, planning and securing funds for programs and projects for Croats abroad, etc. The Office is being managed by the Head, who is in the position of Deputy Minister, appointed by the Government at the proposal of the Prime Minister, whom he also responds to, and he has a Deputy and several advisors (Hrvatski sabor, 2012). Among institutions that are responsible for establishing and developing contacts between Croatia and Croats abroad, the Act mentions the Council of the Government of the Republic of Croatia for the Croats outside the Republic of Croatia, certain ministries, ${ }^{9}$ the Croatian Parliament's Committee on Croats outside the Republic of Croatia, the Croatian Heritage Foundation and other bodies and institutions responsible for relations with Croats outside the Republic of Croatia.

In Montenegro, the key administration body, responsible for relations with diaspora, is Directorate for Diaspora of the Ministry of Foreign Affairs. Apart from the Directorate for Diaspora, very significant subjects responsible for cooperation with diaspora are also the Committee on International Relations and Emigrants of the Parliament of Montenegro, working bodies established at the local level, National Minority Councils, Matica Crnogorska and other organs competent for this issue (Zakon o saradnji Crne Gore sa dijasporom, 2018: 1). As for the Republic of Serbia, institutionally, the Ministry responsible for diaspora has the key role. This institution has the largest number of responsibilities related to diaspora and Serbs in the region, and their relationship with the home country. The Office for Coopera-

9 The Ministries in charge of foreign affairs, internal affairs, science, education, sports, culture, economy, entrepreneurship, labour and pension system, health, social welfare, tourism, regional development and EU funds and finance (Hrvatski sabor, 2012). 
tion with the Diaspora and Serbs in the Region of the Ministry of Foreign Affairs has also an important role. In 2019, the Government of the Republic of Serbia established the Coordination team for the monitoring of economic migration flows in the Republic of Serbia, whose tasks are to elaborate the potential solutions for reducing the 'brain drain' and, at the same time, to provide conditions for utilising the potentials of diaspora, primarily in economic sense. The 2014 Law on Ministries, i.e. its Article 13, specified the responsibilities of the Office for Cooperation with the Diaspora and Serbs in the Region. Wide powers, in terms of monitoring the position of the citizens of the Republic of Serbia in other countries, to help preserve the national and cultural identity of Serbian people, to help maintain the relations with the home country and other affairs, have given the mentioned authority organ a significant place in the institutional framework of the Republic of Serbia related to the diaspora and Serbs in the region (Zakon o ministarstvima [Law on Ministries], 2014: 12). In the Republic of North Macedonia, the issue of migration and emigration has been dealt with by the Ministry of Foreign Affairs, the Agency for Emigrants, Ministry of Labour and Social Policy (IOM, 2009) and, since 2018, the Minister without portfolio in charge of diaspora affairs.

It has already been mentioned that Bosnia and Herzegovina does not have a completed legal framework concerning its diaspora, since there is neither Law nor Strategy on cooperation with diaspora. This has also reflected on the institutional level, as there is no institution that would exclusively deal with the issue. In addition to that, the absence of the so-called "multisectoral approach", which implies the involvement, connection and cooperation of all relevant institutions at each level of political decision-making, undeveloped and almost non-existent formal channels of communication with diaspora, are some of the key problems for Bosnia and Herzegovina in regulating this issue. ${ }^{10}$ There are currently two key institutions competent for this area: Ministry for Human Rights and Refugees of Bosnia and Herzegovina and Ministry of Foreign Affairs of Bosnia and Herzegovina.

In addition to the institutions in charge of diaspora issues, the Republic of Slovenia, the Republic of Croatia, Montenegro and the Republic of Serbia also have advisory bodies with members of diaspora, whose task is to assist in creating and implementing the diaspora policies. In the Republic of Slovenia, those are the Council for Slovenes in Neighbouring Countries - Government's permanent consultative body, which meets twice a year and whose members are elected by the Prime Minister for a five-year mandate, and the Council for Slovenians Abroad,

${ }^{10}$ In order to improve communication with diaspora and provide all the relevant information, activities on drafting a Communications Plan with Diaspora are currently being realised. More details in: Izvještaj o realizaciji aktivnosti na izradi Plana komunikacije sa iseljeništvom (Report on realisation of activities on drafting a Communications Plan with Diaspora), 2018. 
with the same mandate, that meets once a year. In the Republic of Croatia, it is the Council established by the Government and it works as its advisory body, assisting in creating and implementing policies, activities and programmes concerning Croats abroad. Its members are representatives of Croats outside the Republic of Croatia from various associations, organisations and institutions operating outside the country, persons respected in the area they live in, members by position, who are the representatives of the state bodies and institutions, Catholic Church and civil society organisations. Similar is the case of Montenegro, where the Law stipulated the establishment of the Council for Cooperation with Diaspora-Emigrants, as the advisory body with a four-year mandate. The Council consists of diaspora representatives, representatives of the state administration organs, of the Committee on International Relations and Emigrants of the Parliament of Montenegro, municipalities and other institutions and associations, as well as prominent persons who established themselves in the area of cooperation with diaspora. In Serbia, there is the Assembly of the Diaspora and Serbs in the Region, which has 45 delegates and meets once a year. The Assembly establishes the Council for the Diaspora, whose task, as the working body, is to deal more in detail with areas of essential relevance for relations between diaspora and the home country. The Assembly also establishes the Council for relations with Serbs in the region, whose task is to consider all issues relevant to the position of members of Serbian people in the region and their relation with the home country (Zakon o dijaspori i Srbima u regionu, 2009: 7).

\section{The Homelands and Diaspora - Areas of Cooperation}

The first part of the paper emphasised the possibility of different approaches and definitions of diasporas, given the key goals of cooperation between the country of origin and diasporic communities. In the most significant legal acts concerning this area, the states have defined, quite clearly and in detail, the areas of cooperation and activities in regards to diasporic communities, and some of them have also defined the ways of funding the activities aimed at achieving the proclaimed goals. The areas of cooperation between Montenegro and diaspora were clearly defined first by the 2015 Strategy, and then by the Law. There are six key areas of cooperation stipulated by the Law: 1. Preservation of state identity and belonging to Montenegro; 2. Preserving the cultural identity; 3. Strengthening the educational, scientific, cultural and sports cooperation; 4. Informing and connecting; 5. Protection of the rights and position of diaspora - emigrants; 6 . Promotion of economic partnership (Zakon o saradnji Crne Gore sa dijasporom, 2018: 2-4). The purpose of the Strategy for maintaining and strengthening the relations between the homeland and diaspora or between the homeland and Serbs in the region is providing an appropriate range of measures and mechanisms for preserving and strengthening the 
ties between diaspora and the homeland, primarily through "successful development and preservation of Serbian language, Cyrillic script, culture and identity of our citizens and compatriots, who live and work outside the borders of the Republic of Serbia" (Ministarstvo vera i dijaspore. Strategija..., 2011: 3). According to the Strategy, there are three main ways for potential utilisation of diaspora for the homeland's well-being: encouraging the economic development of the Republic of Serbia, using knowledge and skills of highly educated labour force outside the borders of the Republic of Serbia in order to enhance its technological, scientific and other potentials, and using the diasporic communities for successful completion of the integration processes, primarily those in relation to EU (ibid.: 12). The Strategy places particular emphasis on using the social capital of diaspora for increasing the scientific, technological and economic levels of development of the homeland society. The Republic of Serbia's relation towards its diaspora and Serbs in the region differs in the following - in the first case, the emphasis is placed on preservation of ethno-cultural, religious identity and language in the receiving countries, through financing the language lessons and support to the parishes of the Serbian Orthodox Church, which is considered to have the most significant role in preserving identity among diaspora members, in addition to its organisations and associations. In the second case, the Republic of Serbia focuses more on monitoring the legal status of Serbs in the region and protecting their rights and interests.

Croatian Heritage Foundation is an institution defined as a central national institution, whose task is to preserve and develop Croatian national, linguistic and cultural identity of Croats outside the Republic of Croatia, through organising and implementing cultural, scientific, educational, sports, publishing and other activities intended for Croats outside the Republic of Croatia (Hrvatski sabor, 2018). Some of the active measures implemented by the Republic of Croatia in order to protect the rights and interests of Croats abroad are preservation of Croatian language, culture and identity, through the possibility of attending the first semesters of Croatian language in the Republic of Croatia for free, attending Croatian classes among Croatian minority and expatriates, using e-education, encouraging the establishment of departments for Croatian language at universities abroad, and providing the funds for scholarships for students and academic students in their local communities and the Republic of Croatia. According to the Rules on the Award of Support/Scholarships for Croatian Language Learning in the Republic of Croatia, the scholarship costs are covered by the central state budget, while the number of scholarships and their monthly amount for each year are determined by the Head of the Office (Državni tajnik [State Secretary], 2017; Hrvatski sabor, 2012). Similar to the Republic of Croatia, the Republic of Slovenia strives to maintain the relation with its diaspora, primarily through financing the education of young Slovenians living abroad, in two ways. The first one is providing the Slovenian language learn- 
ing abroad, and the second one is providing the scholarships, with intention to motivate young Slovenes to study in the Republic of Slovenia. Slovenian Ministry of Education, Science and Sport finances the additional classes of Slovenian language in many countries Slovenian people live in, in order to preserve and develop Slovenian language among Slovenes worldwide, thus strengthening their Slovenian identity and sense of belonging to the Slovenian nation (Gov.si, 2019; Sklad-kadri.si, 2019). Similar to other former member states of the SFRY, the most significant document on cooperation of Bosnia and Herzegovina with diaspora distinguishes the key goals and aspirations of Bosnia and Herzegovina institutions towards diaspora: including the diasporic communities in the economic and social life of the country, utilising the diaspora potentials for improving the image of Bosnia and Herzegovina in the receiving countries and taking measures in order to preserve the identity of diaspora, in the cultural and national sense (Politika o saradnji sa iseljeništvom [Policy on Cooperation with Diaspora], 2017). The 2018 Foreign Policy Strategy of Bosnia and Herzegovina 2018-2023 states the necessity of intensifying the cooperation with diaspora through strengthening communication, promoting the official languages of Bosnia and Herzegovina, connecting with the diasporic organisations and developing economic diplomacy, which should result in increased economic investments in Bosnia and Herzegovina (Strategija vanjske politike Predsjedništva BiH 2018.-2023., 2018: 10). All the former member states of the SFRY pay particular attention to financing the learning of their mother tongue (and thus preserving identity), and it is implemented in different ways. Bosnia and Herzegovina financed the creation of the Web portal for interactive additional education of children abroad, which was set up in 2018. This portal provides the subject Languages and Literature of the peoples of Bosnia and Herzegovina, in the form of textbooks for I-IV grades of elementary school. What slightly sets the Republic of North Macedonia aside from other states of the former SFRY is a very strong influence that its diaspora has on the politics of its homeland. ${ }^{11}$ Among constitutionally guaranteed rights of diaspora members is the participation in elections in the Republic of North Macedonia, but also a specificity in regards to other states, and that is the election of their own representatives in the national parliament, which causes controversy and debates about the necessity and purpose of their participation.

11 Recently, the Macedonian diaspora, which opposed the change of name and Constitution of the Republic of Macedonia into the Republic of North Macedonia, organised protests against the Government of Zoran Zaev, which initiated and implemented that change. The protests were led by a non-governmental organization United Macedonian Diaspora (UMD), founded in 2004 in Washington in order to gather and promote Macedonian expatriates worldwide. Since 2009, this organisation has been organising an annual conference on the situation and issues in the Republic of North Macedonia, attended by delegates from more than 23 countries Macedonian diaspora exists in. 


\section{Conclusion}

The analysis allows the conclusion that the member states of the former SFRY accept in their legislation the broader, non-classical definition of diaspora, where the diasporic communities members do not necessarily tend to return to their country of origin and they can be completely integrated into the receiving society. The Law on Diaspora - Emigrants of Montenegro even specifies that its diaspora consists of those individuals who intend to settle in the receiving country permanently, with no intention to return to their country of origin. Therefore, this definition of diaspora respects the new circumstances created by the globalisation processes in all dimensions, especially in technological and identity ones. These circumstances allow individuals to maintain relations with their country of origin relatively easily. The possibilities of daily communication and consumption of country-of-origin products, as well as overcoming the space distances relatively easily, create favourable conditions for maintaining a sense of identification and loyalty in regards to the home country. This applies not only to those diasporic communities members of the former republics of the SFRY that belong to recent migratory waves caused by, primarily, socio-economic circumstances, but also to the descendants of the earlier generations of expatriates, who are now given the opportunity to "find" their ancestral homeland again.

Relation between diaspora and country of origin is based on mutual interest and benefits. The home country tends to provide support and protection to its expatriates, while, at the same time, it strives to activate and utilise all the socio-economic and political potentials of diaspora. Thereby, concrete opportunities and activities depend on the particular diasporic community and its context in the receiving country. It is noticeable that most of the countries in question distinct their people members in the region from other countries they live in. The relation to their people members, that is, expatriates in the region, is often a more complex and sensitive area of activity. Relations between the former SFRY republics, burdened by historical ballast and political challenges on a daily basis, in terms of frequent politicisation and instrumentalisation of the ethnic and the national, also reflect on relations between the home countries and their peoples in the region.

In terms of institutional and legal solutions that have been applied in regulating this issue, there has been significant progress in the last decade in all the countries concerned. However, the completeness of legal and institutional frameworks and their coherence are at different levels and of different quality in certain countries.

It is noticeable that Bosnia and Herzegovina faces significant challenges in achieving a unified approach in its policy towards diaspora. Internal disagreements over who constitutes diaspora and the way this issue should be regulated, have resulted in the absence of a law or strategy on diaspora, which in fact means the absence of a clear legal framework and course of action in regards to diaspora. Insti- 
tutionally, these states have generally accepted the solution that the authority at the sub-ministerial level deals with relations towards diaspora, apart from the Republic of Serbia and the Republic of North Macedonia, where the authority responsible for diaspora is a ministry. Despite the competencies related to diaspora being concentrated in one administration body, it is evident that in order to successfully regulate these issues and improve relations with diasporic communities, a multisectoral approach is needed, which would more cohesively link the activities of different organs. In that sense, the practices of the states are different: from the example of the successful multisectoral approach, in the cases of the Republic of Slovenia and the Republic of Croatia, to its complete absence, in the case of Bosnia and Herzegovina. As the migratory trends continue and given the defined strategic fields of cooperation, which include culture, identity elements, economy, science, politics and other areas, it is necessary to further develop a better connection of different institutions that deal with diaspora directly or indirectly. It is only to be expected that diaspora will have a significant influence on political processes in the post-Yugoslav countries in the future. The right-wing political options, which get a part of their political power from their relations with diaspora, will be more inclined to that.

\section{REFERENCES}

Anteby-Yemini, Lisa and Berthomiere, William. 2005. Diaspora: A Look Back on a Concept. Bulletin du Centre de recherche français à Jérusalem, (16): 262-270.

Baučić, Ivo. 1971/1972. Socijalno-ekonomske posljedice vanjskih migracija radne snage iz Jugoslavije. Ekonomski glasnik, (33-34): 25-59.

Bechev, D. 2019. Historical Dictionary of North Macedonia. Rowman \& Littlefield. Lanham.

Bek, Ulrih. 2011. Svetsko rizično društvo. U potrazi za izgubljenom sigurnošću. Akademska knjiga. Novi Sad.

Cohen, Robin. 1996. Diasporas and the State: from Victims to Challengers. International Affairs, (72) 3: 507-520.

Cohen, Robin. 1997. Global Diasporas: An Introduction. UCL Press. London.

Ellis, G. Donald. 2006. Transforming Conflict. Communication and Ethnopolitical Conflict. Rowman \& Littlefield Publishers. Lanham, Boulder, New York, Toronto, Oxford.

Gamlen, Alan. 2014. Diaspora Institutions and Diaspora Governance. International Migration Review, (48) 1: 180-217.

Garding, Sarah. 2018. Weak by design? Diaspora engagement and institutional change in Croatia and Serbia. International Political Science Review, (39) 3: 353-368. 
Halilović, H., Hasić, J., Karabegović, Dž., Karamehić-Muratović, A., Oruč, N. 2018. Mapiranje dijaspore iz Bosne i Hercegovine. Dijaspora za razvoj. Sarajevo.

Koinova, Maria and Tsourapas, Gerasimos. 2018. How do countries of origin engage migrants and diasporas? Multiple actors and comparative perspectives. International Political Science Review, (39) 3: 311-321.

Majnhof, Hana Ulrike and Triandafilidu, Ana. 2008. Šire od dijaspore: transnacionalne prakse kao transkulturni kapital, in: Majnhof, Hana Ulrike and Triandafilidu, Ana (eds.): Transkulturna Evropa. Clio. Beograd: 274-305.

Prešeren, J. 2001. Slovenske sledi v svetu, in: Slovensko izseljenstvo. Zbornik ob 50-letnici Slovenske izseljenske matice. Slovenska izseljenska matica. Ljubljana: 115-125.

Ragazzi, F., Balalovska, K. 2011. Diaspora Politics and Post-Territorial Citizenship in Croatia, Serbia and Macedonia. University of Edinburgh. Edinburgh. Available at: www.law.ed.ac.uk/citsee/workingpapers.

Safran, William. 1991. Diasporas in Modern Societies: Myths of Homeland and Return. Diaspora. A Journal of Transnational Studies, (1) 1: 83-99.

Šolte, Jan Art. 2009. Globalizacija, kritički uvod. CID. Podgorica.

Topolinjska, Z. 1998. In place of a foreword: facts about the Republic of Macedonia and the Macedonian language. International Journal of the Sociology of Language, (131) 1: 31-57.

Žigon, Z. 1993. Problem dvojne identitete slovenskih izseljencev. Diplomsko delo. Fakulteta za družbene vede. Ljubljana.

\section{Documents}

Državni tajnik. 2017. Pravilnik o stipendiranju studenata - pripadnika hrvatskog naroda izvan Republike Hrvatske. Available at: http://www.propisi.hr/print.php?id=15070 (retrieved 2 January 2020).

Državni zbor Republike Slovenije. 1996. Resolucija o položaju avtohtonih slovenskih manjšin $\mathrm{v}$ sosednjih državah in $\mathrm{s}$ tem povezanimi nalogami državnih in drugih dejavnikov Republike Slovenije. Uradni list RS 76/06.

Državni zbor Republike Slovenije. 2006. Zakon o odnosih Republike Slovenije s Slovenci zunaj njenih meja. Uradni list RS 43/06.

Dzs.hr. 2011. Popis stanovništva, kućanstava i stanova 2011. Available at: https://www. dzs.hr/Hrv/censuses/census2011/censuslogo.htm (retrieved 1 January 2020).

Gov.si. 2019. Štipendije za Slovence v zamejstvu in po svetu. Available at: https://www. gov.si/teme/stipendije-za-slovence-v-zamejstvu-in-po-svetu/ (retrieved 4 February 2020).

Hrvatiizvanrh.gov.hr. 2020. Hrvati izvan RH. Available at: https://hrvatiizvanrh.gov.hr/ hrvati-izvan-rh/83 (retrieved 1 February 2020). 
Hrvatski sabor. 2012. Zakon o odnosima Republike Hrvatske s Hrvatima izvan Republike Hrvatske. Available at: https://www.zakon.hr/z/507/Zakon-o-odnosima-Republike-Hrvatske-s-Hrvatima-izvan-Republike-Hrvatske (retrieved 1 January 2020).

Hrvatski sabor. 2014. Ustav Republike Hrvatske. Available at: https://www.zakon. $\mathrm{hr} / \mathrm{z} / 94 /$ Ustav-Republike-Hrvatske (retrieved 1 January 2020).

Hrvatski sabor. 2018. Zakon o Hrvatskoj matici iseljenika. Available at: https://www. zakon.hr/z/1165/Zakon-o-Hrvatskoj-matici-iseljenika (retrieved 1 January 2020).

IOM International Organization for Migration. 2007. THE FORMER YUGOSLAV REPUBLIC OF MACEDONIA MIGRATION PROFILE. Dostupno na http://iom.hu/ PDF/migration_profiles2007/Macedonia_2007.pdf (retrieved 9 January 2020).

Izvještaj o realizaciji aktivnosti na izradi Plana komunikacije sa iseljeništvom. 2018. Available at: https://ijaspora.mhrr.gov.ba/wp-content/uploads/2019/01/IZVJE\%C5\%A0TAJfinalni.pdf (retrieved 30 January 2020).

Ministarstvo vera i dijaspore. Strategija očuvanja i jačanja odnosa matične države i dijaspore i matične države i Srba u regionu. 2011. Available at: https://www.dijaspora. gov.rs/lat/dokumenti-2/ (retrieved 6 February 2020).

Number of migrants now growing faster than world population, new UN figures show. 2019. Available at: https://news.un.org/en/story/2019/09/1046562 (retrieved 20 February 2020).

Obraćanje Ministra za dijasporu, mr Srđana Srećkovića, poslanicima Skupštine Republike Srbije. 2009. Available at: http://www.serbianembassy.jp/SRPSKI/Formulari\%20i\%20slike/Obracanje\%20ministra\%20za\%20dijasporu.pdf (retrieved 15 February 2020).

Politika o saradnji sa iseljeništvom. 2017. Available at: https://dijaspora.mhrr.gov.ba/wpcontent/uploads/2018/01/PolitikaS-final1.pdf (retrieved 30 January 2020).

“SARAJEVO ŽELI VJEŠTAČKU DIJASPORU, Vlada Srpske protiv prenosa nadležnosti u saradnji sa iseljeništvom". 2018. Available at: https://srpskainfo. com/sarajevo-zeli-vjestacku-dijasporu-vlada-srpske-protiv-prenosa-nadleznosti-usaradnji-sa-iseljenistvom/ (retrieved 5 February 2020).

Sklad-kadri.si. 2019. Štipendije za študij Slovencev v zamejstvu in po svetu v Sloveniji. Available at: http://www.sklad-kadri.si/si/stipendije/stipendije-za-studij-slovencevv-zamejstvu-in-po-svetu-v-sloveniji/ (retrieved 4 January 2020).

Strategija vanjske politike Predsjedništva BiH 2018.-2023. 2018. Available at: http:// www.predsjednistvobih.ba/vanj/default.aspx?id=79555\&langTag=bs-BA (retrieved 15 February 2020).

Ustav Republike Srbije. 2006. Available at: http://www.ustavni.sud.rs/page/view/ 139-100028/ustav-republike-srbije (retrieved 30 January 2020).

Vlada Republike Slovenije. 2006a. Odloka o organizaciji in delovnem področju Urada Vlade Republike Slovenije za Slovence v zamejstvu in po svetu. Uradni list RS $60 / 06$. 
Vlada Republike Slovenije. 2006b. Sklep o ustanovitvi, sestavi, organizaciji in nalogah Sveta Vlade Republike Slovenije za Slovence v zamejstvu. Uradni list RS 76/06.

Vlada Republike Slovenije. 2006c. Sklep o ustanovitvi, sestavi, organizaciji in nalogah Sveta Vlade Republike Slovenije za Slovence po svetu. Uradni list RS 76/06.

Vlada Republike Slovenije. 2006d. Uredba o izvajanju finančne podpore za ohranjanje in razvijanje slovenske identitete zunaj Republike Slovenije. Uradni list RS 139/06.

Vlada Republike Slovenije. 2019. Slovenci zunaj Slovenije. Available at: https://www.gov. si/podrocja/zunanje-zadeve/slovenci-zunaj-slovenije/ (retrieved 3 February 2020).

Vlada Crne Gore. Strategija saradnje sa dijasporom za period 2011-2014. 2010. Available at: http://www.gov.me/biblioteka/strategije?=pagerIndex\&AccessibilityFontSi $\mathrm{ze}=150 \% 3 \mathrm{Fquery} \% 3 \mathrm{DUnesite}+$ pojam $\% 3 \mathrm{~A} \% 3 \mathrm{Fquery} \% 3 \mathrm{DUnesite}+$ pojam $\% 3 \mathrm{~A} \& \mathrm{~s}$ ortDirection=Desc\&alphabet $=$ cyr\&pagerIndex $=8$ (retrieved 15 January 2020).

Vlada Crne Gore. Strategija saradnje sa iseljenicima za period 2015-2018. 2015. Available at: http://zakoni.skupstina.me/25saziv/index.php/en/dokumentacija/strategijasaradnje-sa-dijasporom (retrieved 15 January 2020).

Vodič za BH dijasporu. Kako ostvariti prava u BiH?. 2018. Available at: https://dijaspora. mhrr.gov.ba/dokumenti/vodic-o-pravima-dijaspore-iz-bih/(retrieved 3 February 2020).

Zakon o dijaspori i Srbima u regionu. 2009. Available at: http://www.pravno-informacioni-sistem.rs/SlGlasnikPortal/eli/rep/sgrs/skupstina/zakon/2009/88/8/reg (retrieved 14 February 2020).

Zakon o ministarstvima. 2014. Available at: http://www.pravno-informacioni-sistem.rs/ SlGlasnikPortal/eli/rep/sgrs/skupstina/zakon/2014/44/1/reg (retrieved 30 January 2020).

Zakon o saradnji Crne Gore sa dijasporom. 2018. Available at: https://www.paragraf.me/ propisi-crnegore/zakon-o-saradnji-crne-gore-sa-dijasporom-iseljenicima.html (retrieved 30 January 2020).

Mailing Addresses:

Danijela Vuković-Ćalasan, Faculty of Political Sciences, Ulica 13. jula br. 2, 81000 Podgorica, Montenegro.E-mail: danijelacalasan@ucg.ac.me

Siniša Tatalović, Faculty of Political Sciences, Lepušićeva 6, 10000 Zagreb. E-mail: sinisa.tatalovic@fpzg.hr 